\title{
SISTEM PENJADWALAN DISTRIBUSI PRODUK SEPEDA MOTOR MENGGUNAKAN METODE DISTRIBUTION REQUIREMENT PLANNING (DRP) PADA PT. NUSANTARA SURYA SAKTI (NSS) CABANG KEFAMENANU
}

\author{
Yoseph P. K. Kelen*, Oktovianus R. Sikas** \\ * Faculty of Agriculture, Timor University, Kefamenanu, TTU - NTT, Indonesia \\ ** Faculty of Agriculture, Timor University, Kefamenanu, TTU - NTT, Indonesia \\ Correspondence Author: yosepkelen@gmail.com
}

\begin{tabular}{|c|c|}
\hline Info Artikel : & ABSTRACT \\
\hline \multirow[t]{2}{*}{$\begin{array}{l}\text { Sejarah Artikel : } \\
\text { Menerima : 23-12-2018 } \\
\text { Revisi : 19-01-2019 } \\
\text { Diterima : 05-02-2019 } \\
\text { Online : 05-02-2019 } \\
\text { Keyword : } \\
\text { Multi Level } \\
\text { Distribution, } \\
\text { Distribution } \\
\text { Requirement Planning, } \\
\text { Lot Size, } \\
\text { Safety Stock }\end{array}$} & $\begin{array}{l}\text { Motorcycle product distribution at PT. NSS is conducted at the request } \\
\text { of consumers from each region in TTU district. Distribution is run } \\
\text { irregularly or randomly, both in time distribution and quantity. Activity } \\
\text { activities affect the distribution of total inventory costs incurred by the } \\
\text { company in the procurement of inventory. Therefore companies need to } \\
\text { pay attention to the distribution system application activities to optimize } \\
\text { the distribution of motorcycle product delivery schedules to maintain } \\
\text { time and cost efficiency. } \\
\text { Distribution Requirement Planning (DRP) is a method to handle the } \\
\text { procurement of inventory in a multi-level distribution network. The DRP } \\
\text { method relates to the size of the ordering lot and the amount of safety } \\
\text { inventory. The DRP method reduces the total inventory cost and } \\
\text { frequency distribution of activities by determining an effective } \\
\text { scheduling distribution with the consideration that the distribution is } \\
\text { carried out according to lot size or multiples and the amount of safety } \\
\text { stock needed. } \\
\text { Research results, distribution systems and scheduling of motorcycle } \\
\text { product delivery at PT. The NSS Kefamenanu Branch in } 2016 \text { found that } \\
\text { distribution planning with the DRP method was smaller when compared } \\
\text { to the company method. Total Cost (TC) with company method is Rp. } \\
233,391,197.00 \text { and Total Cost (TC) with the DRP method is Rp. } \\
218,460,000.00 \text {. So that there was a decrease of } 6.4 \% \text {. }\end{array}$ \\
\hline & INTISARI \\
\hline $\begin{array}{l}\text { Kata Kunci : } \\
\text { Multi Level } \\
\text { Distribution, } \\
\text { Distribution } \\
\text { Requirement Planning, } \\
\text { Lot Size, } \\
\text { Safety Stock }\end{array}$ & $\begin{array}{l}\text { Distribusi produk sepeda motor di PT. NSS dilakukan atas permintaan } \\
\text { konsumen dari setiap wilayah di kabupaten TTU. Distribusi dijalankan } \\
\text { secara tidak teratur atau acak, baik dalam distribusi waktu atau } \\
\text { kuantitas. Aktifitas kegiatan mempengaruhi distribusi total biaya } \\
\text { persediaan yang dikeluarkan perusahaan dalam pengadaan persediaan. } \\
\text { Oleh karena itu perusahaan perlu memperhatikan aplikasi sistem } \\
\text { distribusi kegiatan untuk mengoptimalkan distribusi jadwal pengiriman } \\
\text { produk sepeda motor untuk menjaga waktu dan efisiensi biaya. } \\
\text { Distribution Requirement Planning (DRP) adalah metode untuk } \\
\text { menangani pengadaan persediaan dalam jaringan distribusi multi-level. } \\
\text { Metode DRP berhubungan dengan ukuran lot pemesanan dan jumlah } \\
\text { persediaan pengaman. Metode DRP mengurangi total biaya persediaan } \\
\text { dan distribusi frekuensi kegiatan dengan menentukan distribusi } \\
\text { penjadwalan yang efektif dengan pertimbangan bahwa distribusi } \\
\text { dilakukan sesuai ukuran lot atau kelipatannya dan jumlah stok } \\
\text { pengaman yang diperlukan. }\end{array}$ \\
\hline
\end{tabular}

ISSN Print $\quad: 1979-7141$ 


\begin{tabular}{|l|l|}
\hline Hasil penelitian, sistem distribusi dan penjadwalan pengiriman produk \\
sepeda motor pada PT. NSS Cabang Kefamenanu tahun 2016 \\
didapatkan perencanaan distribusi dengan metode DRP lebih kecil bila \\
dibandingkan dengan metode perusahaan. Total Cost (TC) dengan \\
metode perusahaan adalah sebesar Rp. 233.391.197,00 dan Total Cost \\
(TC) dengan metode DRP adalah sebesar Rp. 218.460.000,00 . \\
Sehingga terjadi penurunan sebesar 6,4\%.
\end{tabular}

\section{PENDAHULUAN}

Perkembangan dunia usaha sekarang ini mengalami laju pertumbuhan yang sangat pesat, ini ditandai dengan bermunculannya berbagai jenis usaha khususnya dalam bidang manufaktur. Pertumbuhan yang pesat tersebut tentu akan menimbulkan persaingan antara satu perusahaan dengan perusahaan lainnya. Dalam memenangkan persaingan tersebut perusahan menggunakan berbagai cara diantaranya meningkatkan kepuasan pelanggan melalui produk berkualitas, ketepatan waktu pengiriman, dan efisiensi biaya. Kebijaksanaan untuk pengendalian persediaan produk pada suatu lokasi tertentu dapat menimbulkan masalah pada manajemen dalam mengkoordinasikan perencanaan distribusi dari bagian pemasaran, juga pada bagian produksi yang menghasilkan tingkat persediaan produk yang dihasilkan terbaik, sehingga tingkat kepuasan konsumen maupun keuntungan perusahaan dapat terjaga.

PT.NSS Cabang Kefamenanu merupakan perusahaan dilear yang mampu memasok sepeda motor di seluruh wilayah Kabupaten Timor Tengah Utara dan didukung beberapa distributor. Perusahaan telah dipercaya untuk mendistribusikan produknya ke beberapa wilayah di Kabupaten TTU antara lain wilayah Biboki,Insana,Miomafo Timur,Kota Kefamenanu, dan Miomafo Barat. Perusahaan ini memiliki berbagai jenis produk yaitu Revo FIT LP, Revo CW F1 LP, Beat Sporty CBS C LP, Beat Street CBS LP, dan New Beat CBS LP yang memiliki model minimalis. Pengiriman produk dilakukan sesuai dengan permintaan masing-masing distributor dengan menggunakan sarana transportasi darat yang memiliki resiko.

Distribusi yang dilakukan PT.NSS Cabang Kefamenanu didasarkan atas permintaan dari para distributor yang bertindak sebagai warehouse. Di dalam perusahaan ini belum terdapat adanya suatu perencanaan dan penjadwalan aktivitas distribusi produk yang terkoordinasi dengan baik, sehingga permintaan untuk semua masing-masing jenis produk kurang terkontrol sehingga mengakibatkan terjadinya kekurangan atau kelebihan persediaan, baik pada pabrik maupun pada masing-masing warehouse. Dan terdapat produk dengan biaya distribusi yang cukup tinggi. Hal ini didasarkan pada permintaan pelanggan yang cukup tinggi juga.

Dengan adanya masalah tersebut, maka dilakukan perencanaan dan penjadwalan distribusi dengan metode Distribution Requirement Planning (DRP). Diharapkan dengan adanya perencanaan dan penjadwalan aktivitas distribusi yang baik, keberhasilan dalam pemenuhan permintaan pelanggan akan menjadi lebih optimal, kinerja penjualan meningkat dalam memenuhi order dengan tepat waktu dan tepat jumlah sehingga biaya distribusi dapat ditekan seminimun mungkin.

\section{METODE PENELITIAN}

Biaya yang dikeluarkan oleh suatu perusahaan dalam aktivitas distribusi adalah biaya total persediaan. Metode DRP adalah suatu metode untuk menangani pengadaan persediaan dalam suatu jaringan distribusi multi tingkat. Metode DRP dapat menekan total biaya persediaan dengan merencanakan penjadwalan distribusi. 


\section{a. Economic Order Quantity (EOQ)}

Model EOQ (Economic Order Quantity Model) sering juga dinamakan model ukuran tumpuk sederhana. EOQ menunjukkan jumlah barang yang harus dipesan untuk setiap kali pemesanan agar biaya sediaan keseluruhan menjadi sekecil mungkin dan merupakan salah satu sistem persediaan berdasarkan permintaan bebas.

$$
E O Q=\sqrt{\frac{2 x R m x C}{H}}
$$

Di mana,

$$
\begin{aligned}
\mathrm{EOQ} & =\text { Jumlah pemesanan yang ekonomis atau terhemat (unit) } \\
\mathrm{Rm} & =\text { rata }- \text { rata tingkat permintaan (unit) } \\
\mathrm{C} & =\text { biaya pemesanan ( } \text { order cost) } \\
\mathrm{H} & =\text { biaya penyimpanan (holding cost) }
\end{aligned}
$$

\section{b. Safety Stock (SS)}

Safety Stock (SS) adalah persedian yang dimaksudkan untuk mengatasi ketidak-pastian pada permintaan, masa tunggu, dan penawaran. Masa tunggu (lead time) adalah jarak waktu sejak pesanan diajukan hingga barang atau bahan dipesan diterima.

Formulasi Safety Stock (SS) adalah

$$
S=(B-R m) L
$$

Dimana,

$$
\begin{aligned}
& S=\text { safety stock } \\
& B=\text { Titik reorder (Maksimum permintaan setiap produk) } \\
& R m=\text { Rata-rata demand } \\
& L=\text { Lead time }
\end{aligned}
$$

\section{c. Distribution Requirement Planning (DRP)}

Distribution Requirement Planning adalah suatu metode untuk menangani pengadaan persediaan dalam suatu jaringan distribusi multi eselon. Metode ini menggunakan demand independent, dimana dilakukan peramalan untuk memenuhi struktur pengadaannya. Berapapun banyaknya level yang ada dalam jaringan distribusi, semuanya merupakan variabel yang dependent kecuali level yang langsung memenuhi consumer. Distribution Requiremeni Planning lebih menekankan pada aktivitas pengendalian dari pada kegiatan pemesanan. DRP mengantisipasi kebutuhan mendatang dengan perencanaan pada setiap level pada jaringan distribusi. Metode ini dapat memprediksi masalah-masalah sebelum masalah-masalah tersebut benar-benar terjadi memberikan titik pandang terhadap jaringan distribusi. Logika dasar $D R P$ adalah sebagai berikut :

1. Gross Requirement /Forecast Demand diperoleh dari hasil forecasting.

2. Dari hasil peramalan distribusi lokal, hitung Time Phased Net Requirement. Net Requirement tersebut mengidentifikasikan kapan level persediaan (Scheduled Receipt - Projected On Hand Periode sebelumnya) dipenuhi oleh Gross Requirement. Untuk sebuah periode : Net Requirement $=($ Gross Requirement + Safety Stock $)-($ Schedule Receipt + Projected On Hand Periode sebelumnya). Nilai Net Requirement yang dicatat (recorded) adalah nilai yang bernilai positif. 
3. Setelah itu dihasilkan sebuah Planned Order Receipt sejumlah Net Requirement tersebut (ukuran lot tertentu) pada periode tersebut.

4. Ditentukan hari dimana harus melakukan pemesanan tersebut (Planned Order Release) dengan mengurangkan hari terjadwalnya Planned Order Receipt dengan Lead Time.

5. Di hitung Projected On Hand pada periode tersebut:

Projected On Hand = $($ Projected On Hand Periode sebelumnya + Schedule Receipt

+ Planned Order Receipt) - (Gross Requirement).

6. Besarnya Planned Order Release menjadi Gross Requirement pada periode yang sama untuk level berikutnya dari jaringan distribusi (Richard J. Tersine, 1994, hal 465).

\section{HASIL DAN ANALISA}

\subsection{Data Penelitian}

Data meliputi data primer dan data sekunder. Data primer berupa hasil penelitian lapangan dan wawancara kepada pihak Perusahaan mengenai penelitian, sedangkan data sekunder adalah hasil dokumentasi dengan cara mengutip dari catatan-catatan perusahaan, antara lain data historis permintaan, data persediaan produk, data lead time, data biaya simpan, dan biaya kirim. Data-data yang diperoleh dan dibutuhkan dalam penelitian ini adalah:

1. Data permintaan $(\mathrm{R})$

Data permintaan diperoleh langsung dari perusahaan PT NSS Cabang Kefamenanu berupa dafatar permintaan produk sepeda motor di wilayah Kabupaten Timor Tengah Utara. Datadata produk sepeda motor yang digunakan dalam penelitian ini yaitu Revo FIT LP, Revo CW F1 LP, Beat Sporty CBS C LP, Beat Street CBS LP, dan New Beat CBS LP. Data dapat dilihat pada tabel-tabel berikut:

Tabel 1 Data Produk Revo FIT LP

\begin{tabular}{|c|c|c|c|c|c|}
\hline \multirow[t]{2}{*}{ No } & Warehouse & \multirow{2}{*}{$\begin{array}{c}\mathrm{K} \\
\text { (unit) }\end{array}$} & \multirow{2}{*}{$\begin{array}{c}\mathrm{N} \\
\text { (unit) }\end{array}$} & \multirow{2}{*}{$\begin{array}{c}\text { I } \\
\text { (unit) }\end{array}$} & \multirow{2}{*}{$\begin{array}{c}\text { B } \\
\text { (unit) }\end{array}$} \\
\hline & Bulan & & & & \\
\hline 1 & Januari & 31 & 27 & 32 & 2 \\
\hline 2 & Februari & 2 & 20 & 27 & 37 \\
\hline 3 & Maret & 6 & 19 & 4 & 21 \\
\hline 4 & April & 32 & 9 & 20 & 18 \\
\hline 5 & Mei & 30 & 25 & 23 & 28 \\
\hline 6 & Juni & 20 & 12 & 23 & 22 \\
\hline 7 & Juli & 8 & 2 & 6 & 20 \\
\hline 8 & Agustus & 11 & 18 & 9 & 38 \\
\hline 9 & September & 36 & 26 & 19 & 14 \\
\hline 10 & Oktober & 2 & 18 & 4 & 24 \\
\hline 11 & November & 25 & 5 & 27 & 28 \\
\hline 12 & Desember & 11 & 11 & 25 & 2 \\
\hline \multicolumn{2}{|r|}{ Total } & 214 & 192 & 219 & 254 \\
\hline
\end{tabular}


Tabel 2 Data Produk Revo CW F1 LP

\begin{tabular}{|c|c|c|c|c|c|}
\hline \multirow[t]{2}{*}{ No } & Warehouse & \multirow{2}{*}{$\begin{array}{c}\mathrm{K} \\
\text { (unit) }\end{array}$} & \multirow{2}{*}{$\begin{array}{c}\mathrm{N} \\
\text { (unit) }\end{array}$} & \multirow{2}{*}{$\begin{array}{c}\text { I } \\
\text { (unit) }\end{array}$} & \multirow{2}{*}{$\begin{array}{c}\text { B } \\
\text { (unit) }\end{array}$} \\
\hline & Bulan & & & & \\
\hline 1 & Januari & 20 & 16 & 17 & 20 \\
\hline 2 & Februari & 8 & 9 & 15 & 3 \\
\hline 3 & Maret & 4 & 3 & 5 & 11 \\
\hline 4 & April & 17 & 4 & 16 & 1 \\
\hline 5 & Mei & 18 & 1 & 16 & 20 \\
\hline 6 & Juni & 17 & 20 & 19 & 10 \\
\hline 7 & Juli & 12 & 20 & 11 & 12 \\
\hline 8 & Agustus & 6 & 16 & 7 & 7 \\
\hline 9 & September & 17 & 16 & 6 & 19 \\
\hline 10 & Oktober & 16 & 9 & 1 & 20 \\
\hline 11 & November & 3 & 5 & 2 & 15 \\
\hline 12 & Desember & 16 & 7 & 3 & 20 \\
\hline & Total & 154 & 126 & 118 & 158 \\
\hline
\end{tabular}

Keterangan: $K=$ Kota-Bikomi-Miotim; $N=$ Noemuti-Miobar;

$I=$ Insana dan $B=$ Biboki

Tabel 3 Data Produk New Beat CBS LP

\begin{tabular}{|c|c|c|c|c|c|}
\hline \multirow{2}{*}{ No } & Warehouse & $\begin{array}{c}\text { K } \\
\text { (unit) }\end{array}$ & $\begin{array}{c}\text { N } \\
\text { (unit) }\end{array}$ & $\begin{array}{c}\text { I } \\
\text { (unit) }\end{array}$ & $\begin{array}{c}\text { B } \\
\text { (unit) }\end{array}$ \\
\hline 1 & Januari & 10 & 6 & 10 & 7 \\
\hline 2 & Februari & 2 & 17 & 13 & 6 \\
\hline 3 & Maret & 16 & 13 & 17 & 8 \\
\hline 4 & April & 11 & 19 & 11 & 5 \\
\hline 5 & Mei & 10 & 11 & 14 & 16 \\
\hline 6 & Juni & 15 & 11 & 5 & 13 \\
\hline 7 & Juli & 20 & 1 & 8 & 14 \\
\hline 8 & Agustus & 10 & 10 & 14 & 8 \\
\hline 9 & September & 4 & 15 & 3 & 1 \\
\hline 10 & Oktober & 5 & 9 & 5 & 3 \\
\hline 11 & November & 11 & 17 & 16 & 10 \\
\hline 12 & Desember & 12 & 9 & 3 & 8 \\
\hline \multicolumn{7}{|c|}{ Total } & $\mathbf{1 2 6}$ & $\mathbf{1 3 8}$ & $\mathbf{1 1 9}$ & $\mathbf{9 9}$ \\
\hline
\end{tabular}

Keterangan: $K=$ Kota-Bikomi-Miotim; $N=$ Noemuti-Miobar;

$I=$ Insana dan $B=$ Biboki 
Tabel 4 Data Produk Beat Street CBS LP

\begin{tabular}{|c|c|c|c|c|c|}
\hline \multirow{2}{*}{ No } & Warehouse & \multirow{2}{*}{$\underset{\text { (unit) }}{\mathrm{K}}$} & \multirow{2}{*}{$\begin{array}{c}\mathrm{N} \\
\text { (unit) }\end{array}$} & \multirow{2}{*}{$\begin{array}{c}\text { I } \\
\text { (unit) }\end{array}$} & \multirow{2}{*}{$\underset{\text { (unit) }}{\text { B }}$} \\
\hline & Bulan & & & & \\
\hline 1 & Januari & 3 & 1 & 6 & 9 \\
\hline 2 & Februari & 2 & 6 & 10 & 14 \\
\hline 3 & Maret & 8 & 3 & 13 & 11 \\
\hline 4 & April & 6 & 7 & 7 & 2 \\
\hline 5 & Mei & 14 & 10 & 3 & 4 \\
\hline 6 & Juni & 10 & 8 & 2 & 7 \\
\hline 7 & Juli & 11 & 2 & 2 & 9 \\
\hline 8 & Agustus & 13 & 1 & 12 & 1 \\
\hline 9 & September & 2 & 5 & 2 & 6 \\
\hline 10 & Oktober & 1 & 14 & 7 & 3 \\
\hline 11 & November & 13 & 5 & 3 & 11 \\
\hline 12 & Desember & 11 & 1 & 4 & 9 \\
\hline \multicolumn{2}{|r|}{ Total } & 94 & 63 & 71 & 86 \\
\hline
\end{tabular}

Keterangan: $K=$ Kota-Bikomi-Miotim; $N=$ Noemuti-Miobar;

$I=$ Insana dan $B=$ Biboki

Tabel 5 Data Produk Beat Sporty CBS C LP

\begin{tabular}{|c|c|c|c|c|c|}
\hline \multirow{2}{*}{ No } & Warehouse & \multirow{2}{*}{$\begin{array}{c}\mathrm{K} \\
\text { (unit) }\end{array}$} & \multirow{2}{*}{$\begin{array}{l}\mathrm{N} \\
\text { (unit) }\end{array}$} & \multirow{2}{*}{$\begin{array}{c}\text { I } \\
\text { (unit) }\end{array}$} & \multirow{2}{*}{$\stackrel{\mathrm{B}}{\text { (unit) }}$} \\
\hline & Bulan & & & & \\
\hline 1 & Januari & 3 & 2 & 9 & 2 \\
\hline 2 & Februari & 2 & 7 & 5 & 1 \\
\hline 3 & Maret & 10 & 7 & 4 & 4 \\
\hline 4 & April & 9 & 1 & 8 & 6 \\
\hline 5 & Mei & 8 & 2 & 8 & 8 \\
\hline 6 & Juni & 9 & 1 & 2 & 1 \\
\hline 7 & Juli & 3 & 6 & 4 & 1 \\
\hline 8 & Agustus & 2 & 4 & 6 & 6 \\
\hline 9 & September & 8 & 4 & 9 & 1 \\
\hline 10 & Oktober & 8 & 10 & 6 & 6 \\
\hline 11 & November & 7 & 3 & 1 & 1 \\
\hline 12 & Desember & 9 & 9 & 7 & 6 \\
\hline & Total & 78 & 56 & 69 & 43 \\
\hline
\end{tabular}

Keterangan: $K=$ Kota-Bikomi-Miotim; $N=$ Noemuti-Miobar;

$I=$ Insana dan $B=$ Biboki

2. Inventory On Hand Desember 2016

Tabel 6 Data Inventory On Hand Desember 2016

\begin{tabular}{|l|c|}
\hline \multicolumn{1}{|c|}{ Warehouse } & Produk (unit) \\
\hline Kota-Miotim (K) & 10 \\
\hline Noemuti-Miobar (N) & 10 \\
\hline Insana (I) & 10 \\
\hline Biboki (B) & 10 \\
\hline
\end{tabular}

Sumber : PT. NSS Cabang Kefamenanu 
3. Harga Produk

Tabel 7 Data Harga Produk

\begin{tabular}{|l|c|}
\hline \multicolumn{1}{|c|}{ Produk } & Harga \\
\hline Revo Fit LP & Rp. 16.126 .000 \\
\hline Revo CW F1 LP & Rp. 17.826 .000 \\
\hline New Beat CBS LP & Rp. 17.936 .000 \\
\hline Beat Street CBS LP & Rp. 18.136 .000 \\
\hline Beat Sporty CBS C LP & Rp. 18.586 .000 \\
\hline \multicolumn{2}{|c|}{ Sumber : PT. NSS Cabang Kefamenanu }
\end{tabular}

4. $\quad$ Lead Time

Tabel 8 Data Lead Time

\begin{tabular}{|l|c|}
\hline \multicolumn{1}{|c|}{ Warehouse } & Lead Time \\
\hline Kota-Miotim (K) & 1 \\
\hline Noemuti-Miobar (N) & 1 \\
\hline Insana (I) & 1 \\
\hline Biboki (B) & 1 \\
\hline
\end{tabular}

5. Data Biaya Pemesanan (order cost) (C)

Tabel 9 Data Biaya Pemesanan (order cost) $(\mathrm{C})$

\begin{tabular}{|c|c|c|c|c|}
\hline Rincian Biaya & $\bar{K}$ & $\mathrm{~N}$ & I & $\mathrm{B}$ \\
\hline Biaya administrasi & Rp. 15.000 & Rp. 15.000 & Rp. 15.000 & Rp. 15.000 \\
\hline Biaya tenaga kerja & Rp. 25.000 & Rp. 25.000 & Rp. 25.000 & Rp. 25.000 \\
\hline Biaya Sopir & Rp. 25.000 & Rp. 25.000 & Rp. 25.000 & Rp. 25.000 \\
\hline Bensin & Rp. 100.000 & Rp. 150.000 & Rp. 170.000 & Rp. 200.000 \\
\hline Total & Rp. 825.000 & Rp. 1.075 .000 & Rp. 1.175 .000 & Rp. 1.325 .000 \\
\hline
\end{tabular}

6. Data biaya penyimpanan (holding cost) $(\mathrm{H})$

Prosentase biaya penyimpanan suatu produk adalah sebesar 5\% per tahun, sehingga diperoleh biaya penyimpanan tiap periode perencanaan ( 1 tahun $=12$ bulan) adalah $\frac{5 \%}{12}=0,42 \%$. Dengan demikian biaya penyimpanan tiap periode perencanaan adalah $0,42 \%$ per bulan dari harga produk. Secara rinci diperoleh hasil dengan rumus, Biaya Simpan $=$ Harga produk $\mathrm{x}$ Biaya Penyimpanan (output pada tabel berikut):

Tabel 10 Nilai Prosentas biaya penyimpanan

\begin{tabular}{|l|c|c|r|}
\hline \multicolumn{1}{|c|}{ Produk } & Harga Produk & $\begin{array}{c}\text { Prosentase Biaya } \\
\text { penyimpanan /tahun }\end{array}$ & $\begin{array}{c}\text { Nalai Prosentasi } \\
\text { Biaya Simpan/tahun }\end{array}$ \\
\hline Revo Fit LP & Rp. 16.126.000 & $0,42 \%$ & Rp. 67.729 \\
\hline Revo CW F1 LP & Rp. 17.826.000 & $0,42 \%$ & Rp. 74.869 \\
\hline New Beat CBS LP & Rp. 17.936.000 & $0,42 \%$ & Rp.75.331 \\
\hline Beat Street CBS LP & Rp. 18.136.000 & $0,42 \%$ & Rp. 76.171 \\
\hline Beat Sporty CBS C LP & Rp. 18.586.000 & $0,42 \%$ & Rp. 78.061 \\
\hline \multicolumn{3}{|c|}{ Total Biaya Simpan } \\
\hline
\end{tabular}

Sumber : PT. NSS Cabang Kefamenanu 
Tabel 11 Total Biaya penyimpanan

\begin{tabular}{|c|c|c|c|c|c|}
\hline \multirow{2}{*}{ Warehouse } & \multicolumn{5}{|c|}{ Produk } \\
\hline & Tipe 1 & Tipe 2 & Tipe 3 & Tipe 4 & Tipe 5 \\
\hline $\mathrm{K}$ & 214 & 154 & 126 & 94 & 78 \\
\hline $\mathrm{N}$ & 192 & 126 & 138 & 63 & 56 \\
\hline I & 219 & 118 & 119 & 71 & 69 \\
\hline B & 254 & 158 & 99 & 86 & 43 \\
\hline Total Produk & 879 & 556 & 482 & 314 & 246 \\
\hline $\begin{array}{l}\text { Persen Harga } \\
\text { Produk }\end{array}$ & Rp. 67.729 & Rp. 74.869 & Rp. 75.331 & Rp. 76.171 & Rp. 78.061 \\
\hline $\begin{array}{l}\text { Total Biaya } \\
\text { Simpan }\end{array}$ & Rp $\quad 59.533 .791$ & $\mathrm{Rp} \quad 41.627 .164$ & $\mathrm{Rp} \quad 36.309 .542$ & 23.917.694 & $\mathrm{Rp} \quad 19.203 .006$ \\
\hline \multicolumn{4}{|c|}{ Total Biaya Simpan } & \multicolumn{2}{|c|}{ Rp 180.591.197 } \\
\hline
\end{tabular}

\subsection{Pengolahan Data}

\subsubsection{Perhitungan Biaya Distribusi dengan Metode Perusahaan}

Pada bagian ini perusahaan melakukan proses perbandingan biaya sistem distribusi selama 1 tahun. Perhitungan total biaya logistik digunakan data bulanan selama tahun 2016. Lebih lanjut didapat total biaya pengiriman selama 1 tahun seperti pada tabel 12 dengan cara frekuensi kirim $\mathrm{x}$ biaya kirim per bulan.

Tabel 12 Grand Total Biaya Kirim

\begin{tabular}{|c|c|c|c|}
\hline Warehouse & $\begin{array}{c}\text { Frekuensi } \\
\text { Kirim }\end{array}$ & Biaya Kirim & $\begin{array}{c}\text { Total Biaya } \\
\text { Kirim }\end{array}$ \\
\hline K & 12 & Rp. 825.000 & Rp. 9.900 .000 \\
\hline N & 12 & Rp. 1.075 .000 & Rp. 12.900 .000 \\
\hline I & 12 & Rp. 1.175 .000 & Rp. 14.100 .000 \\
\hline B & 12 & Rp. 1.325 .000 & Rp. 15.900 .000 \\
\hline \multicolumn{3}{|c|}{ Grand Total } & RP. 52.800.000 \\
\hline
\end{tabular}

Dari perhitungan biaya distribusi perusahaan diperoleh total penyimpanan dan total biaya pengiriman. Kemudian mencari total biaya distribusi perusahaan dengan perhitungan sebagai berikut:

Biaya Distribusi = Biaya penyimpanan + Biaya pengiriman

$=\operatorname{Rp} 180,591,197+\operatorname{Rp} \cdot 52 \cdot 800.000$

$=\operatorname{Rp} 233,391,197$

Dengan menggunakan metode perusahaan, didapat grand total cost distribusi sebesar Rp 233,391,197 selama 1 tahun.

\subsubsection{Perhitungan Sistem Distribusi dengan Menggunakan Metode Distribusi Requirement} Planning (DRP)

\section{a. Economic Order Quantity (EOQ)}

Perhitungan EOQ masing-masing tipe produk pada setiap warehouse dapat dilihat pada lampiran IV. Untuk produk tipe 1 pada wilayah $\mathrm{K}$ adalah:

$R m=\frac{31+2+6+32+30+20+8+11+36+2+25+11}{12}$ 


$$
\begin{aligned}
R m & =\frac{214}{12}=17,833 \\
C & =R p \cdot 825.000 / \text { kirim } \\
H & =\text { Rp. } 67.729 / \text { unit } \\
\text { EOQ } & =\sqrt{\frac{2 \cdot R m \cdot C}{H}}=\sqrt{\frac{2 \times(17,8333) \times 825.000}{67.729}} \\
& =20,84 \approx 21 \text { unit }
\end{aligned}
$$

Perhitungan EOQ dilakukan dengan menggunakan software Matlab 2013a dan output proses EOQ sebagai beriut:

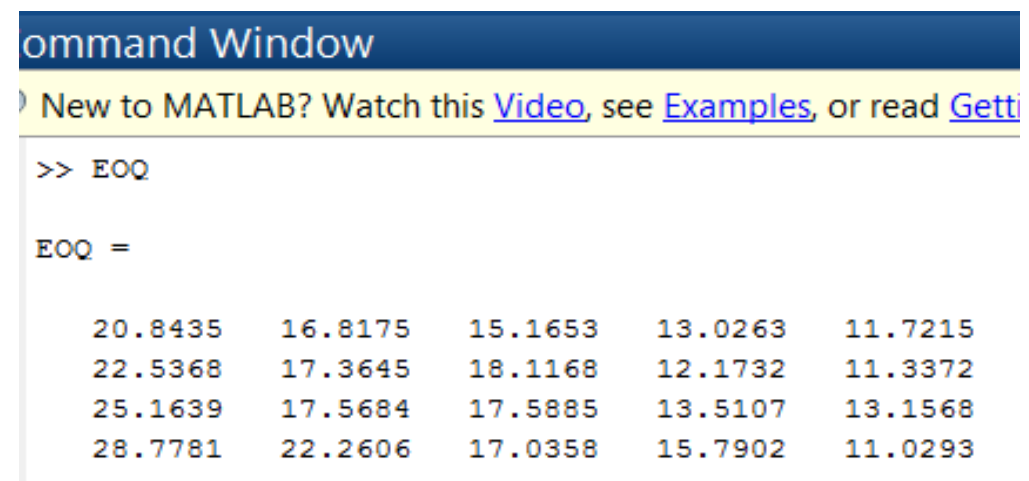

Pembulatan output perhitungan EOQ di atas dapat disajikan secara lengkap pada tabel 13 .

Tabel 13 Economic Order Quantity (EOQ)

\begin{tabular}{|c|c|c|c|c|c|}
\hline \multirow{2}{*}{ Warehouse } & \multicolumn{5}{|c|}{ Economic Order Quantity (EOQ) } \\
\cline { 2 - 6 } & Tipe 1 & Tipe 2 & Tipe 3 & Tipe 4 & Tipe 5 \\
\hline K & 21 & 17 & 15 & 13 & 12 \\
\hline N & 22 & 17 & 18 & 12 & 11 \\
\hline I & 25 & 18 & 18 & 14 & 13 \\
\hline B & 29 & 22 & 17 & 16 & 11 \\
\hline
\end{tabular}

\section{b. Safety Stock (SS)}

Perhitungan safety stock untuk produk Revo Fit I wilayah Kota-Miotim $(\mathrm{K})$ :

$$
\begin{aligned}
R m & =\frac{31+2+6+32+30+20+8+11+36+2+25+11}{12} \\
& R m=\frac{214}{12}=17,833 \\
& \mathrm{~B}=\max (\mathrm{Ka})=36 \\
& L=1 \text { bulan } \\
& S=(36-17,833) x 1=18,1667 \approx 18
\end{aligned}
$$

Perhitungan Safety Stock (SS) dilakukan dengan menggunakan software Matlab 2013a dan output proses Safety Stock (SS) sebagai beriut: 


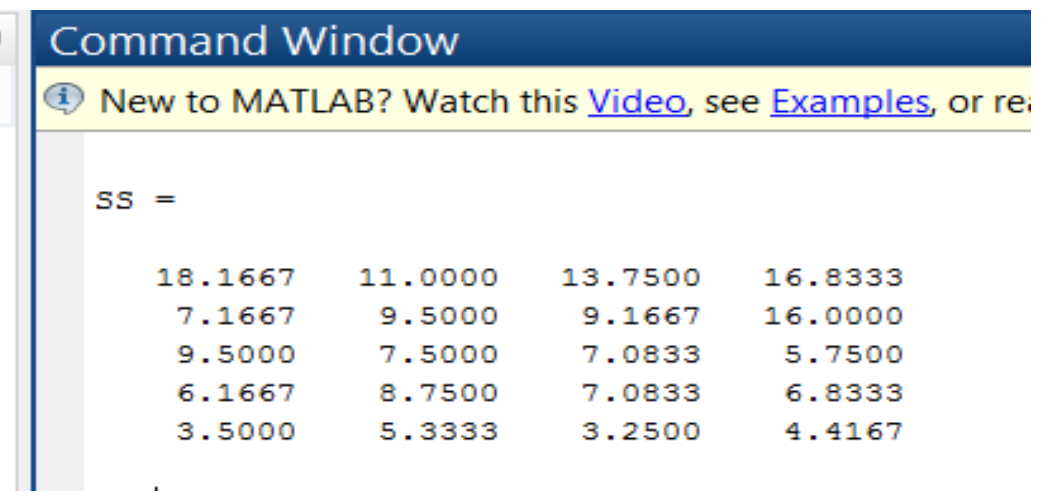

Pembulatan output perhitungan Safety Stock (SS) di atas dapat disajikan secara lengkap pada tabel 14.

Tabel 14 Safety Stock (SS)

\begin{tabular}{|c|c|c|c|c|c|}
\hline \multirow{2}{*}{ Wilayah } & \multicolumn{5}{|c|}{ Safety Stock (SS) } \\
\cline { 2 - 6 } & Tipe 1 & Tipe 2 & Tipe 3 & Tipe 4 & Tipe 5 \\
\hline K & 18 & 7 & 10 & 6 & 4 \\
\hline N & 11 & 10 & 8 & 9 & 5 \\
\hline I & 14 & 9 & 7 & 7 & 3 \\
\hline B & 17 & 16 & 6 & 7 & 4 \\
\hline
\end{tabular}

\section{c. Distribusi Requirement Planning (DRP)}

Adapun data-data yang dibutuhkan :

1) Data kebutuhan kotor (Gross Requirement) yaitu data permintaan pada tabel 1 sampai dengan tabel 5

2) Data ukuran lot yaitu hasil perhitungan $E O Q$ setiap produk pada tabel 13

3) Data Safety Stock (SS) pada tabel 14

4) Data Projected On Hand ( $\mathrm{POH}$ ) atau Persediaan di tangan pada tabel 6

Perhitungan Distribusi Requirement Planning (DRP) untuk produk sepeda motor tipe Revo FIT LP adalah:

$$
\begin{gathered}
(\mathrm{NR})_{t}=\left[(\mathrm{GR})_{t}+\mathrm{SS}\right]-\left[(\mathrm{SR})_{t}+(\mathrm{POH})_{t-1}\right] \\
=31+18-[0+10] \\
=39 \\
(\mathrm{POH})_{t}=\left[(\mathrm{POH})_{t-1}+(\mathrm{SR})_{t}+(\mathrm{POReC})_{t}\right]-(\mathrm{GR})_{t} \\
=(10+0+31)-31 \\
=10 \text { unit }
\end{gathered}
$$

Perhitungan Distribution Requirement Planning (DRP) untuk masing-masing produk selengkapnya dapat dilihat pada lampiran IV. Pada tabel 15 merupakan hasil perhitungan $D R P$ untuk produk sepeda motor Revo FIT LP pada warehouse Kota-Miomafo Timur. 
Tabel 15 Hasil DRP Revo FIT LP Warehouse K

\begin{tabular}{|c|c|c|c|c|c|c|c|c|c|c|c|c|c|c|}
\hline $\mathrm{POH}$ & \multicolumn{10}{|l|}{$: 10$} & \multicolumn{3}{|c|}{ Lot Size } & 21 \\
\hline \multirow[t]{3}{*}{ SS } & \multicolumn{10}{|l|}{$: 18$} & \multicolumn{3}{|c|}{ Lead time } & 1 \\
\hline & \multirow{2}{*}{$\begin{array}{l}\text { Past } \\
\text { Due }\end{array}$} & \multicolumn{12}{|c|}{ Periode (Unit) } & Jumlah \\
\hline & & 1 & 2 & 3 & 4 & 5 & 6 & 7 & 8 & 9 & 10 & 11 & 12 & \\
\hline GR & 0 & 31 & 2 & 6 & 32 & 30 & 20 & 8 & 11 & 36 & 2 & 25 & 11 & 214 \\
\hline SR & 0 & 0 & 0 & 0 & 0 & 0 & 0 & 0 & 0 & 0 & 0 & 0 & 0 & 0 \\
\hline $\mathrm{POH}$ & 10 & 10 & 29 & 6 & 4 & 2 & 10 & 12 & 37 & 5 & 34 & 2 & 14 & 165 \\
\hline NR & 0 & 39 & 10 & 30 & 44 & 44 & 36 & 40 & 30 & 17 & 25 & 9 & 27 & 216 \\
\hline PORec & 0 & 21 & 0 & 0 & 28 & 28 & 10 & 0 & 0 & 31 & 0 & 23 & 0 & 113 \\
\hline PORel & 21 & 0 & 0 & 0 & 28 & 28 & 10 & 0 & 0 & 31 & 0 & 23 & 0 & 113 \\
\hline
\end{tabular}

Dengan hasil pada tabel 15 diperoleh:

$$
\begin{aligned}
& \text { Biaya Simpan }=\text { Persediaan ditangan } \times \text { biaya penyimpanan } \\
& =165 \times \text { Rp. } 67.729 \\
& =\text { Rp. } 11.175 .285 \\
& \begin{aligned}
& \text { Biaya Pesan }=\text { Jumlah Kendaraan } \times \text { Biaya pemesanan } \\
&=\text { (Jumlah PORec: } 24) \times \text { Rp. } 825.000 \\
&=(113: 24) \times \text { Rp. } 825.000 \\
&= \text { Rp. } 3.884 .000 \\
& \text { Biaya Persediaan }=\text { Biaya simpan }+ \text { Biaya pesan } \\
&=\text { Rp. } 11.175 .285+\text { Rp. } 3.884 .000 \\
&=\text { Rp. } 15.060 .000
\end{aligned}
\end{aligned}
$$

Dengan menggunakan software Matlab 2013a diperoleh total biaya persediaan produk tahun 2016 pada setiap warehouse adalah sebagai berikut:

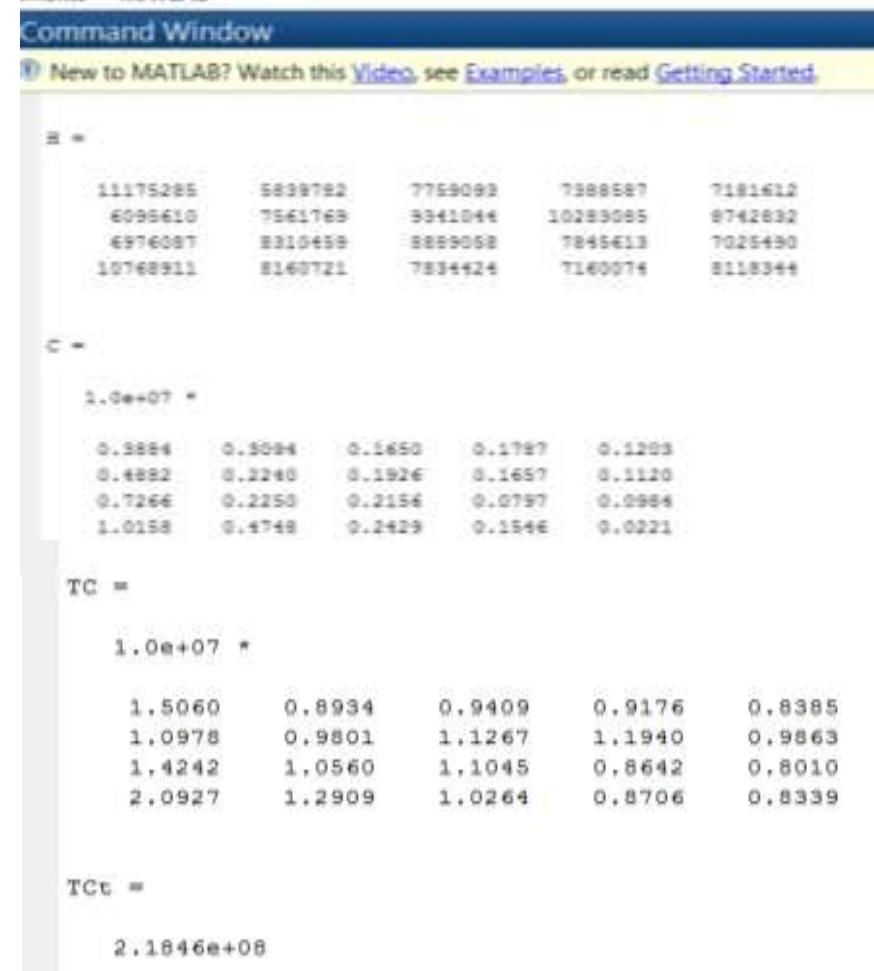

ISSN Print $\quad: 1979-7141$

ISSN Online : 2541-1942 
Pembulatan output total biaya persediaan produk pada setiap warehouse dapat dijabarkan pada tabel berikut.

Tabel 16 Grand Total Biaya Persediaan Produk

\begin{tabular}{|c|c|c|c|c|c|}
\hline \multirow{2}{*}{ Produk } & \multicolumn{5}{|c|}{ Biaya Persediaan } \\
\hline & $\mathrm{K}$ & & $\mathrm{N}$ & I & B \\
\hline 1 & Rp 15.060.000 & $\mathrm{Rp}$ & 10.978 .000 & $\mathrm{Rp} 14.242 .000$ & Rp $\quad 20.927 .000$ \\
\hline 2 & $\mathrm{Rp} \quad 8.934 .000$ & $\mathrm{Rp}$ & 9.801 .000 & Rp 10.560 .000 & Rp 12.909 .000 \\
\hline 3 & Rp 9.409 .000 & $\mathrm{Rp}$ & 11.267 .000 & $\mathrm{Rp} 11.045 .000$ & $\mathrm{Rp} \quad 10.264 .000$ \\
\hline 4 & $\mathrm{Rp} \quad 9.176 .000$ & $\mathrm{Rp}$ & 11.940 .000 & Rp 8.642 .000 & Rp $\quad 8.706 .000$ \\
\hline 5 & $\mathrm{Rp} \quad 8.385 .000$ & $\mathrm{Rp}$ & 9.863 .000 & Rp 8.010 .000 & Rp $\quad 8.339 .000$ \\
\hline $\mathrm{TC}$ & Rp 50.964.000 & $\mathrm{Rp}$ & 53.849 .000 & Rp 52.499.000 & Rp 61.145 .000 \\
\hline \multicolumn{5}{|c|}{ Grand Total } & Rp 218.460.000 \\
\hline
\end{tabular}

\subsection{Analisa Dan Pembahasan}

Dari hasil pengolahan data diperoleh hasil analisa dan pembahasan sebagai berikut :

1. Perbandingan biaya

Setelah melakukan perhitungan distribusi produk sesuai dengan kondisi riil perusahaan dan perhitungan distribusi produk menggunakan metode $D R P$, didapatkan perbandingan biaya yang tertera pada Tabel 17 .

Tabel 17. Perbandingan biaya distribusi perusahaan dan DRP

\begin{tabular}{|c|l|c|}
\hline & \multicolumn{1}{|c|}{ Metode } & Biaya \\
\hline 1 & Perusahaan & Rp. 233.391.197 \\
\hline 2 & DRP & Rp. 218.460.000 \\
\hline
\end{tabular}

Perencanaan distribusi metode yang digunakan perusahaan yaitu perencanaan distribusi didasarkan atas permintaan warehouse pusat. Total Cost (TC) dengan metode perusahaan adalah sebesar Rp. 233.391.197,00,-. Total Cost (TC) dengan metode DRP adalah sebesar Rp. 218.460.000,00,-. Hasil perbandingan Total Cost didapatkan bahwa Total Cost dengan selisih antara metode perusahaan dengan metode $D R P$ yaitu:

$$
\text { Rp. 233.391.197,00 - Rp. 218.460.000,00 = Rp. 14.931.197,00 }
$$

Dengan persentase,

$$
\frac{233.391 .197-218.460 .000}{233.391 .197} \times 100 \%=6,4 \%
$$

2. Dari hasil perbandingan Total Cost didapatkan bahwa Total Cost dengan metode DRP lebih kecil bila dibandingkan dengan metode perusahaan dan terjadi efisiensi sebesar $6,4 \%$. Hal ini membuktikan bahwa metode DRP lebih efisien bila diterapkan pada perusahaan PT. NSS Cabang Kefamenanu, sehingga digunakan untuk memperkirakan kebutuhan pada periode berikutnya yaitu pada tahun 2017 . 


\section{KESIMPULAN (11 PT)}

Dari hasil perancangan penjadwalan distribusi pada PT NSS Cabang Kefamenanu dengan menggunakan metode Distribution Requirement Planning (DRP) dapat mengatasi permasalahan pemenuhan kebutuhan produk dimana meminimasi penumpukan dan kekosongan persediaan produk pada setiap warehouse. Pada perancangan penjadwalan distribusi usulan didapatkan ratarata pemenuhan masing-masing produk pada tiap bulan Januari 2016 sampai Desember 2016 mendekati kebutuhan setiap warehouse. Hasil perencanaan penjadwalan distribusi produk untuk wilayah Kota-Miomaffo Timur, Noemuti-Miomaffo Barat, Insana dan Biboki sebagai berikut: Hasil perencanaan dan pendistribusian produk sepeda motor dengan metode pada PT NSS Cabang Kefamenanu memperoleh Total Cost (TC) adalah sebesar Rp. 233.391.197,- sedangkan ketika menggunakan metode DRP Total Cost (TC) adalah sebesar Rp. 218.460.000,-. Dengan demikian mengalami penurunan sebesar $6,4 \%$.

\section{ACKNOWLEDGEMENTS}

Paper ini dihasilkan dari penelitian yang dibiayai oleh Lembaga Penelitian dan pengabdian Masyarakat (LPPM) Universitas Timor T.A.2018.

\section{DAFTAR PUSTAKA}

Hakim, Arman. dan prasetyawan. Yudha, 2008, Perencanaan dan Pengendalian Produksi. PT Graha Ilmu, Yogyakarta

Handayani, Putu, 2011, Perencanaan Penjadwalan Distribusi Produk Dengan Metode Distribution Requirement Planning (DRP), Jurnal, Universitas Pembangunan Nasional "veteran", Jawa Timur.

Desi, Mufti, 2012, Penerapan Distribution Requirement Planning Pada aktivitas Distribusi Sepeda Motor Honda, Jurnal, Universitas Bung Hatta, Padang.

Gaspersz, Vincent, 2004, Production planning and Inventory Control, PT. Gramedia Pustaka Utama: Jakarta.

Purnomo, Hari, 2003, Pengantar Teknik Industri, PT Graha Ilmu, Yogyakarta.

Juliansyah, Deka, 2011, Sistem Informasi Distribusi Barang Menggunakan Metode Distribution Requirement Planning (DRP), Jurnal, Universitas Bina Darma, Palembang.

Ishak, Aulia, 2010, Manajemen Operasi, PT. Graha Ilmu : Yogyakarta

Fahrozi, Adib Abdilah, 2009, Perencanaan Penjadwalan Aktifitas Distribusi Hasil Perikanan Dengan Menggunakan Distribution Requirement Planning (DRP), Jurnal, Universitas Pembangunan Nasional "veteran", Jawa Timur.

Tersine, Richard J. 1994. Principles of Inventory and Materials Management. Edisi Keempat. Prentice Hall, Inc. USA. 